\title{
Rapid Eye Movement (REM) Sleep Behavior Disorder and REM Sleep with Atonia in the Young
}

\author{
Garima Shukla, Anupama Gupta, Kamalesh Chakravarty, Angela Ann Joseph, \\ Aathira Ravindranath, Manju Mehta, Sheffali Gulati, Madhulika Kabra, \\ Afsar Mohammed, Shivani Poornima*
}

\begin{abstract}
Background: Rapid eye movement (REM) sleep behavior disorder (RBD) and REM sleep without atonia (RWA) have assumed much clinical importance with long-term data showing progression into neurodegenerative conditions among older adults. However, much less is known about RBD and RWA in younger populations. This study aims at comparing clinical and polysomnographic (PSG) characteristics of young patients presenting with RBD, young patients with other neurological conditions, and normal agematched subjects. Methods: A retrospective chart review was carried out for consecutive young patients ( $<25$ years) presenting with clinical features of RBD; and data were compared to data from patients with epilepsy, attention deficit hyperactivity disorder (ADHD), and autism, as well as normal subjects who underwent PSG during a 2-year-period. Results: Twelve patients fulfilling RBD diagnostic criteria, 22 autism patients, 10 with ADHD, 30 with epilepsy, and 14 normal subjects were included. Eight patients with autism (30\%), three with ADHD (30\%), one with epilepsy (3.3\%), and six patients who had presented with RBD like symptoms (50\%) had abnormal movements and behaviors during REM sleep. Excessive transient muscle activity and/or sustained muscle activity during REM epochs was found in all patients who had presented with RBD, in 16/22 (72\%) autistic patients, 6/10 (60\%) ADHD patients compared to only $6 / 30(20 \%)$ patients with epilepsy and in none of the normal subjects. Conclusion: We observed that a large percentage of young patients with autism and ADHD and some with epilepsy demonstrate loss of REM-associated atonia and some RBD-like behaviors on polysomnography similar to young patients presenting with RBD.
\end{abstract}

RÉSUMÉ: Troubles du comportement en sommeil paradoxal et sommeil paradoxal sans atonie musculaire chez les jeunes. Contexte: Les troubles du comportement en sommeil paradoxal (TCSP) et le sommeil paradoxal sans atonie musculaire ont acquis une grande importance clinique. En effet, des données à long terme ont montré de quelle façon ils pouvaient progresser chez des adultes âgés atteints de maladies neurodégénératives. Toutefois, on en sait beaucoup moins au sujet des TCSP et du sommeil paradoxal sans atonie musculaire au sein des groupes d'âges plus jeunes. Cette étude entend donc comparer les caractéristiques cliniques et polysomnographiques (PSG) de jeunes patients donnant à voir des signes de TCSP à celles d'autres jeunes patients atteints d'autres troubles neurologiques et de sujets en bonne santé appariés en fonction de l'âge. Méthodes: Nous avons passé en revue de façon rétrospective les dossiers de jeunes patients ( $<25$ ans) donnant à voir des signes cliniques de TCSP et ayant été vus consécutivement. Les données recueillies ont été comparées aux données de patients atteints d'épilepsie, de troubles de l'attention avec hyperactivité et d'autisme ainsi qu'à celles de sujets en bonne santé soumis à des examens de PSG pendant une période de deux ans. Résultats: Au total, on a diagnostiqué chez 12 patients des TCSP. Ajoutons que 22 d'entre eux étaient atteints d'autisme alors que 10 étaient atteints de troubles de l'attention avec hyperactivité et 30 d'épilepsie. Mentionnons par ailleurs que 14 sujets en bonne santé ont été inclus dans cette étude. Après analyse, il s'est avéré que 8 patients atteints d'autisme (30 \%), 3 de troubles de l'attention avec hyperactivité $(30 \%), 1$ d'épilepsie (3,3\%) et 6 ayant donné à voir des symptômes ressemblant à ceux des TCSP (50 \%) montraient des mouvements et des comportement anormaux en sommeil paradoxal. Des signes d'activité musculaire transitoire excessive et/ou d'activité musculaire durable lors d'épisodes de sommeil paradoxal ont été détectés chez tous les patients satisfaisant aux critères des TCSP, chez 16 patients autistes sur $22(72 \%)$, chez 6 patients atteint de troubles de l'attention avec hyperactivité sur 10 (60\%) en comparaison avec seulement 6 patients épileptiques sur 30 (20\%) et aucun parmi les sujets en bonne santé. Conclusion: Lors d'examens polysomnographiques, nous avons en définitive observé qu'une forte proportion de jeunes patients atteints d'autisme et de troubles de l'attention avec hyperactivité, ainsi que quelques-uns atteints d'épilepsie, donnaient à voir des signes de perte de sommeil paradoxal associés à l'atonie musculaire ainsi que des comportements ressemblant à ceux de jeunes patients atteints de TCSP.

Keywords: REM sleep behavior disorder, REM sleep without atonia, Children, Young, Autism, ADHD, Epilepsy

doi: $10.1017 / \operatorname{cjn} .2019 .302$

Can J Neurol Sci. 2020; 47: 100-108

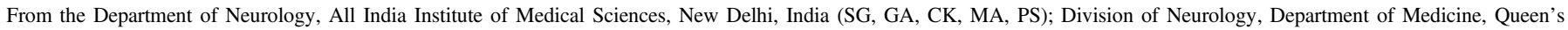

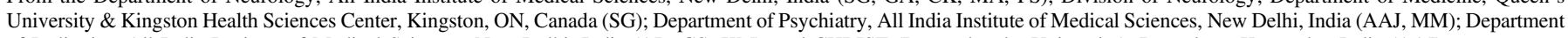
of Pediatrics, All India Institute of Medical Sciences, New Delhi, India (AR, GS, KM); and CHRIST (Deemed to be University), Bengaluru, Karnataka, India (AAJ)

Received April 14, 2019. Final Revisions Submitted September 16, 2019. Date of Acceptance September 18, 2019.

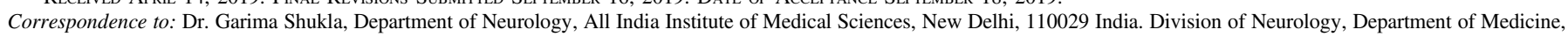
Queen's University \& Kingston Health Sciences Center, Kingston, ON K7L2V7, Canada. Emails: gs108@queensu.ca; garimashukla@hotmail.com

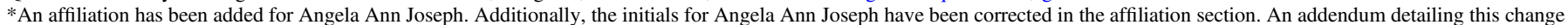
has also been published (doi:10.1017/cjn.2020.132). 


\section{INTRODUCTION}

While many rapid eye movement (REM) sleep parasomnias have been described, a vast majority comprise the REM sleep behavior disorder (RBD), which is largely an illness seen among elderly males. ${ }^{1}$ The clinical significance of RBD is now well established, not only for its medicolegal implications due to the violent nature of the abnormal movements during sleep but also mainly for the progression in more than $80 \%$ of patients with RBD to a neurodegenerative disorder, mostly synucleinopathies. ${ }^{2}$ Over the past decades, a number of case reports have also described many conditions, which can have RBD as a manifestation of underlying neurological illness, for example, narcolepsy, brainstem lesions, encephalitis, autism, and others. ${ }^{3-8}$ Among these, many patients are younger than the usual age of presentation of the commoner idiopathic RBD which may precede or is co-existent with neurodegenerative conditions such as Parkinson's disease, dementia with Lewy bodies, or multiple system atrophy.

The entity of REM sleep without atonia (RWA) has assumed much clinical importance since it is the essential polysomnographic (PSG) manifestation of RBD. The long-term clinical significance of isolated RWA remains a subject of investigation. ${ }^{9}$

The current study aims at evaluating clinical and PSG characteristics of young patients diagnosed to have RBD and to compare their REM sleep features with age-matched healthy controls and with patients suffering from autism, attention deficit hyperactivity disorder (ADHD), and epilepsy.

\section{Methods}

This is a retrospective chart review-based study, including young subjects from the Neurology services sleep disorders facility at our center, an apex quaternary-care academic center, over a 2-year study period between 2012 and 2014 .

\section{Study Subjects}

Consecutive young subjects, who were less than 25 years of age and who underwent video-PSG at our center, formed the study population. These were classified into the following groups:

(i) patients diagnosed with $\mathrm{RBD}$, having been evaluated through the sleep disorders facility for abnormal behaviors during sleep,

(ii) patients with autism spectrum disorder,

(iii) patients with ADHD,

(iv) patients with epilepsy, and

(v) healthy age-matched control subjects

all of whom were in the same age group and underwent videoPSG during the same study period.

Patients with an established video-PSG diagnosis of non-rapid eye movement (NREM) parasomnia and unconscious or otherwise medically serious patients were excluded. Those with no REM period recorded during the PSG night were also excluded.

The "normal controls" were from a group enrolled in another ongoing study on children and adolescents with autism. All of them had been screened for sleep complaints and were asymptomatic for the same.

\section{Video-PSG Procedure}

As a routine for all the PSGs, overnight polysomnography (PSG) study had been performed by trained sleep technologists, according to the latest version of the American Academy of Sleep Medicine (AASM) scoring manual, for all subjects. ${ }^{10}$ The monitored parameters included left and right electrooculogram, extended electroencephalogram (EEG), mental and submental electromyogram (EMG), left and right anterior tibialis EMG, single electrocardiogram waveform, snoring, continuous airflow via thermistor, nasal pressure transducer, chest and abdominal effort, oxygen saturation, and body position, which was also confirmed through video monitoring.

For the patients in group (i), additional EMG channels with electrodes having been placed on the left extensor digitorum and the right deltoid muscles were also recorded. A 16 channel EEG was also obtained as part of the detailed protocol for evaluation of patients with suspected parasomnias.

For patients in group (iv) also, 16 channel EEG had been obtained in addition to the PSG hook-up described above.

\section{Video-PSG Interpretation}

Definitions of all PSG parameters as well as specific diagnosis, for example, Obstructive sleep apnea and periodic limb movement disorder, were based on AASM guidelines. ${ }^{10}$

Clinical details of behaviors recorded during REM sleep (and other stages) had been noted and shown to carers, to ascertain habitual nature of the same, in case of patients who had presented to the clinic for abnormal behaviors during sleep.

\section{Specific REM Sleep Analysis}

For the purpose of this study, REM epochs of all subjects included were re-scored by two independent scorers (BS and AG). The following parameters were analyzed and tabulated, for each group:

a. total number of REM epochs during PSG night

b. REM percentage of total sleep time

c. Total number of REM epochs with excessive transient muscle activity (ETMA) or sustained muscle activity (SMA)*

d. Percentage of REM epochs with ETMA or SMA

e. Number (\%) and percentage of epochs with $\geq 50 \%$ of 10-second mini-epochs with ETMA and/or SMA

f. Number $(\%)$ and percentage of epochs with $\geq 20 \%$ of 10 -second mini-epochs with ETMA and/or SMA

g. Number (\%) subjects in each group with $\geq 5 \%$ of REM epochs showing ETMA and/or SMA in $\geq 20 \%$ of the epoch * SMA (tonic activity) in REM sleep: An epoch of REM sleep with at least $50 \%$ of the duration of the epoch having a chin EMG amplitude greater than the minimum amplitude demonstrated in NREM sleep.

ETMA (phasic activity) in REM sleep: In a 30-second epoch of REM sleep divided into 10 sequential 3-second mini-epochs, at least $5(50 \%)$ of the mini-epochs contain bursts of transient muscle activity. In RBD, ETMA bursts are 0.1-5.0 seconds in duration and at least four times as high in amplitude as the background EMG activity.

Based on AASM manual version 2.3. ${ }^{10}$ 
Table 1: Age/Sex distribution and REM sleep analysis of young subjects included in various clinical categories

\begin{tabular}{|c|c|c|c|c|c|}
\hline Variable & Normal controls $(N=14)$ & Autism $(N=22)$ & ADHD $(N=10)$ & $\begin{array}{c}\text { Clinic patients presenting } \\
\text { as RBD }(N=12)\end{array}$ & Epilepsy $(N=30)$ \\
\hline \multicolumn{6}{|l|}{ Age } \\
\hline Mean + SD & $9.69 \pm 1.93$ & $5.16 \pm 2.30$ & $8.1 \pm 1.72$ & $13.73 \pm 7.76$ & $19.5 \pm 5.74$ \\
\hline Median (range) & $10(6-11)$ & $5(5-12)$ & $7.5(7-11)$ & $13(3-25)$ & $19(9-25)$ \\
\hline Sex (Male) $(\%)$ & 12 & 16 & 10 & 12 & 19 \\
\hline \multicolumn{6}{|c|}{ REM sleep percentage of total sleep time } \\
\hline Mean + SD & $15.14 \pm 8.24$ & $7.54 \pm 5.4$ & $13.73 \pm 7.84$ & $17.56 \pm 5.9$ & $12.85 \pm 8.11$ \\
\hline Median (range) & $15(1-24)$ & $7(1-50)$ & $13(3-36)$ & $17(5-38)$ & $12(1-23.49)$ \\
\hline \multicolumn{6}{|c|}{ Total number of REM epochs during PSG night } \\
\hline Mean \pm SD & $147.5 \pm 42.6$ & $84.13+69.7$ & $106.1 \pm 35.6$ & $186.54 \pm 82.27$ & $109.42 \pm 62.12$ \\
\hline Median (range) & $135(79-256)$ & $71(4-258)$ & $117(36-145)$ & $148(120-380)$ & $108(1-238)$ \\
\hline $\begin{array}{l}\text { Number of patients with } \\
\text { RWA N }(\%)^{*}\end{array}$ & 0 & $16(72.22)$ & $6(60)$ & $12(100)$ & $6(20)$ \\
\hline $\begin{array}{l}\text { Number of patients }(\%) \text { with } \\
\text { abnormal behaviors } \\
\text { recorded on video } \\
\text { corresponding to periods } \\
\text { of RWA, suggestive of } \\
\text { RBD }\end{array}$ & 0 & $8(36)$ & $3(30)$ & $7(58)$ & $1(3)$ \\
\hline
\end{tabular}

$\mathrm{ADHD}=$ attention deficit hyperactive disorder; REM = rapid eye movement; RWA = REM sleep without atonia.

Sustained muscle activity (tonic activity) in REM sleep: An epoch of REM sleep with at least 50\% of the duration of the epoch having a chin EMG amplitude greater than the minimum amplitude demonstrated in NREM sleep.

Excessive transient muscle activity (phasic activity) in REM sleep: In a 30-second epoch of REM sleep divided into 10 sequential 3-second mini-epochs, at least $5(50 \%)$ of the mini-epochs contain bursts of transient muscle activity. In RBD, excessive transient muscle activity bursts are $0.1-5.0$ seconds in duration and at least four times as high in amplitude as the background EMG activity.

*RWA defined based on AASM scoring manual $(2007)^{10}$ version 2.3 guidelines.

\section{Diagnosis of RBD}

The diagnosis of RBD was made strictly in accordance with the criteria described in the International Classification for Sleep disorders, version $3,{ }^{11}$ while RWA (also a requirement for the diagnosis of RBD) was diagnosed in accordance with the AASM guidelines manual version 2.3. ${ }^{10}$

Parameters (f.) and (g.) mentioned under the previous subheading were computed for further quantification of the PSG abnormalities observed during REM sleep of included subjects, especially those not fulfilling AASM criteria for RWA.

\section{ReSUlTS}

During the study period, a total of 102 subjects in the specified age group were identified, who had undergone technically adequate polysomnography for at least one night. Among these, 32 had autism spectrum disorder, 10 of whose PSG studies recorded no REM epochs. Hence 22 from this group were included. PSG studies of 18 normal children were available, out of which 4 had no REM sleep recorded. Apart from these, there were 10 PSG studies of children with ADHD and 30 of those with epilepsy, which were analyzed. The rest were those of 12 patients who had presented to the clinic with episodic abnormal behavior during sleep and whose PSG did not identify findings supporting the diagnosis of NREM parasomnia or seizures. Hence, PSG studies of a total of 88 subjects were available for detailed REM sleep analysis.
This was a male-dominant population, with all 12 suspected RBD patients, 16/22 with autism, all 10 ADHD, 19/30 epilepsy patients, and 12/14 normal controls being male. Gender matching was not possible since this is a retrospective study, and it was important to include all consecutive patients in each group. Age range in various groups has been mentioned in Table 1.

Apart from the 12 patients who had presented with possible parasomnias, no other subjects included had history of abnormal behavior during sleep.

Limited details of imaging obtained for patients in included groups were available at the time of analysis:

Autism - Imaging was done among 19 out of 22 patients, 17 reported normal, 1 showed Ischemic changes in bilateral parietooccipital regions, and 1 had right frontal lobe dysplasia.

ADHD - MRI conducted whenever required clinically, but not as a part of study.

Epilepsy - All patients underwent either MRI or CT scans; nearly half of these were abnormal with focal brain lesions

RBD - Eleven patients underwent MRI/CT Scan. One MRI was reported abnormal - possible diffuse hypoxic ischemic changes over widespread regions bilaterally.

The average number of REM epochs $(85.47 \pm 70.12)$ and REM percentage $(7.54 \pm 5.4)$ was lowest in the group of 
Table 2: REM characteristics of subjects manifesting RWA

\begin{tabular}{|c|c|c|c|c|}
\hline Variable & Autism $(N=22)$ & $\operatorname{ADHD}(N=10)$ & Clinic patients $(N=12)$ & Epilepsy $(N=30)$ \\
\hline $\begin{array}{l}\text { Number of patients with REM } \\
\text { epochs showing }>50 \% \text { of } \\
\text { ETMA and/or SMA }\end{array}$ & $16(72.22)$ & $6(60)$ & $12(100)$ & $6(20)$ \\
\hline \multicolumn{5}{|l|}{ Total number of REM epochs } \\
\hline Mean \pm SD & $85.47+70.1$ & $108+38.09$ & $183+79.23$ & $127+63.23$ \\
\hline Median (range) & $71(4-258)$ & $117(36-149)$ & $148(120-380)$ & $129(40-198)$ \\
\hline \multicolumn{5}{|c|}{ Number of REM epochs with RWA ( $>50 \%$ occupied by ETMA/SMA) } \\
\hline Mean \pm SD & $4.25+3.51$ & $14.5+10.6$ & $29.67+33.36$ & $3.0+2.76$ \\
\hline Median (range) & $3.5(1-14)$ & $13.5(3-29)$ & $12(3-103)$ & $1.5(1-7)$ \\
\hline \multicolumn{5}{|c|}{ Percentage of mini-epochs having EMA } \\
\hline Mean \pm SD & $19.64+23.2$ & $15.05+15.7$ & $33.83+24.1$ & $3.79+2.88$ \\
\hline Median (range) & $11.76(3.62-100)$ & $8.78(2.06-48.4)$ & $25.35(7.43-80.7)$ & $3.78(0.53-7.5)$ \\
\hline
\end{tabular}

$\mathrm{ADHD}=$ attention deficit hyperactive disorder; REM = rapid eye movement; RWA = REM sleep without atonia; ETMA = excessive transient muscle activity; SMA = sustained muscle activity; EMA = excessive muscle activity.

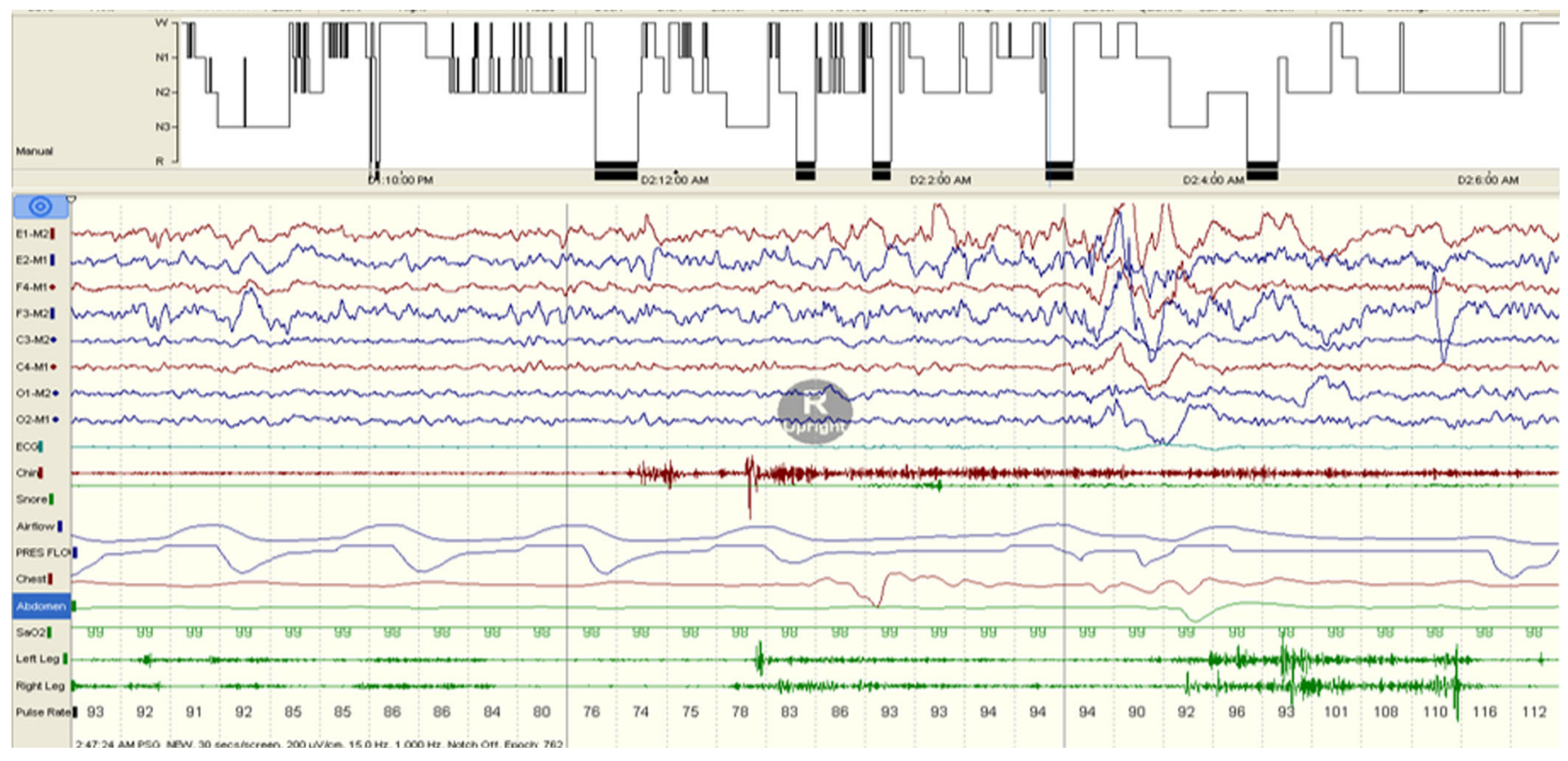

Figure 1: Sustained muscle activity (SMA).

patients with autism and highest in clinic patients who had presented with suspected RBD $(183 \pm 79.23)$. Expectedly, the latter was also the group with maximum number and percentage of REM epochs with ETMA and/or SMA. ETMA and/or SMA during REM epochs was found in all clinic patients diagnosed with RBD, in $16 / 22(72 \%)$ autistic patients, 6/10 (60\%) ADHD patients compared to only 6/30 (20\%) patients with epilepsy, and none of the normal subjects (Table 2) (Figures 1-3).

On analysis of video on the video-PSG, eight patients among autistic and three among ADHD subjects were observed to have non-specific body movements during REM sleep ranging from sudden jerky movements of limbs or head, rolling of legs, repetitive but not stereotyped movements of upper limbs with occasional crying. One patient in the epilepsy sub-group had nonspecific upper limb movements without any concomitant ictal EEG correlates. Details of clinical presentation of patients in the suspected RBD group are listed; details of associated conditions and medication history along with the video-PSG findings for this group are described in Table 3.

All patients diagnosed with RBD were treated with $0.125-$ $0.25 \mathrm{mg}$ of nightly Clonazepam and at a mean follow-up of $6 \pm 5.66$ months; they were all free from symptoms of the nocturnal events. Apart from oral Clonazepam, one patient who was on multiple narcotic drugs underwent successful deaddiction over a period of 4 months, two patients who were receiving selective serotonin reuptake inhibitor (SSRI) medications tapered the same off, while the two patients who were 


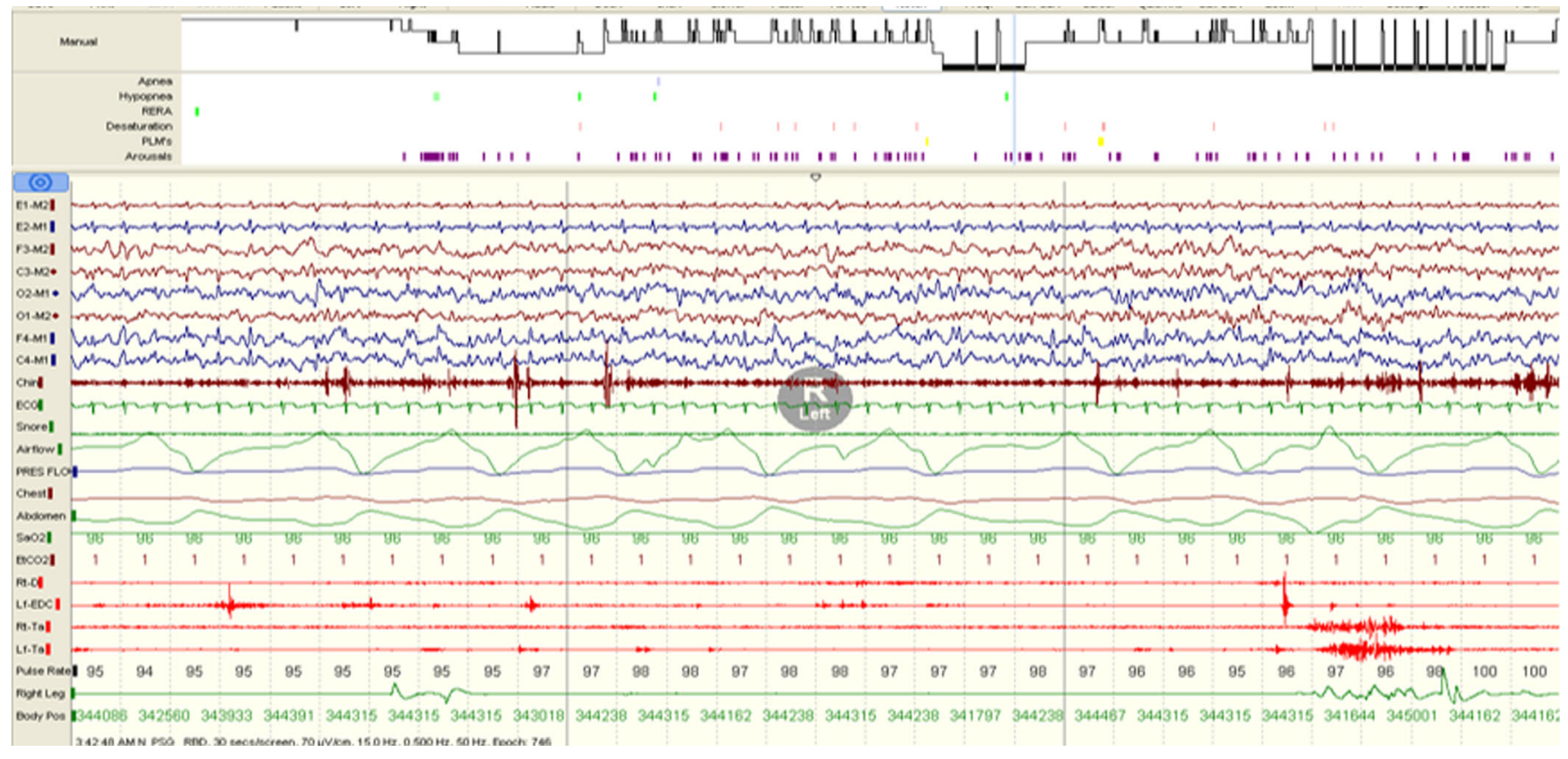

Figure 2: Excessive transient muscle activity (ETMA).

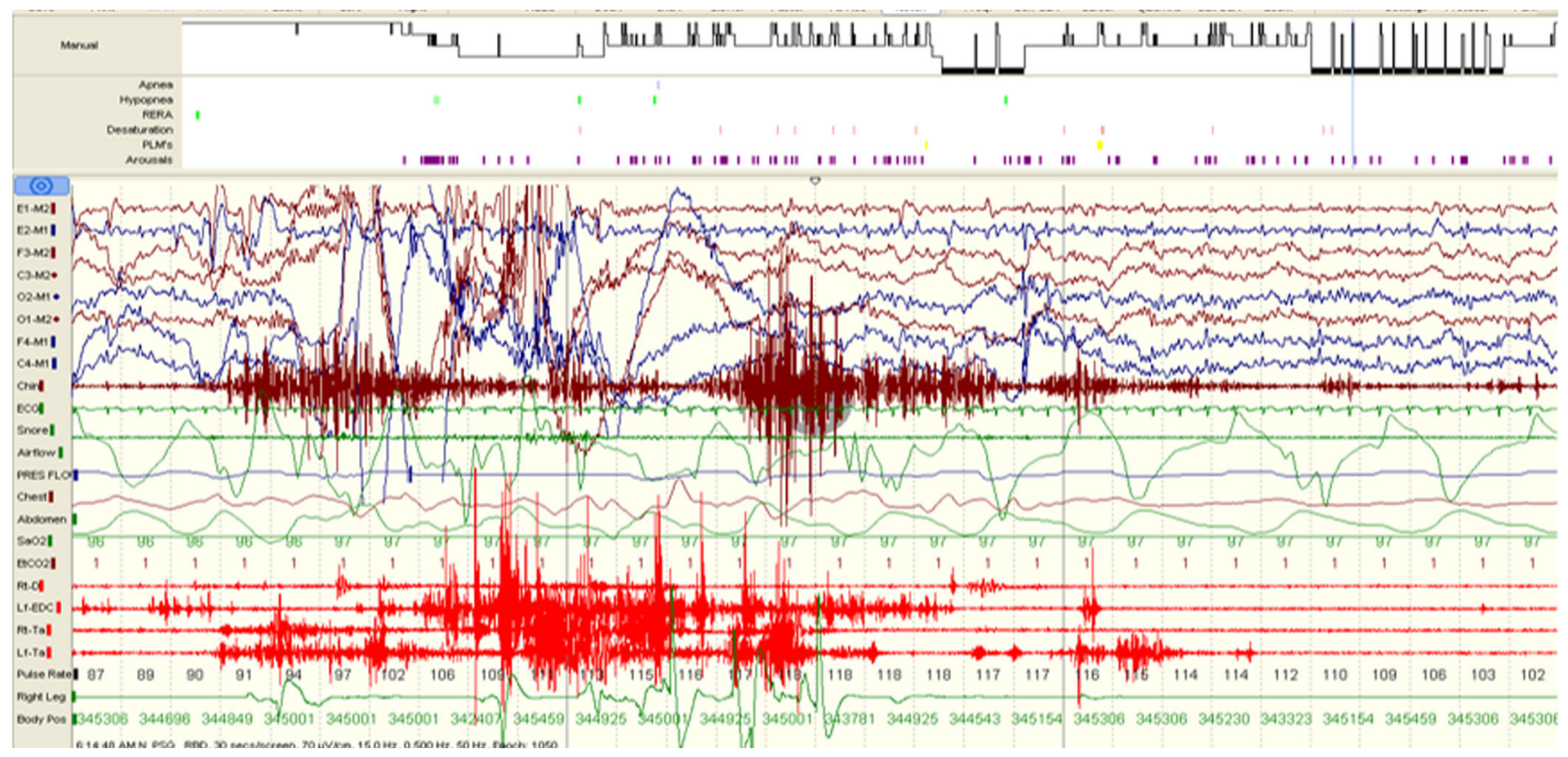

Figure 3: Sustained muscle activity (SMA) and excessive transient muscle activity (ETMA).

diagnosed to have narcolepsy continued to remain on the tricyclic anti-depressant (TCA) medication which had been prescribed to them.

Medications used in different groups studied were as follows:

- ADHD: Atomoxetine, Methylphenidate, and Sodium valproate

- Autism: Risperidone, Olanzapine, Atomoxetine, Sodium valproate, Carbamazepine, and Levetiracetam

- Epilepsy: Oxcarbazepine, Carbamazepine, Levetiracetam, Sodium valproate, Lacosamide, and Clobazam.
Patients in all groups, who did not demonstrate RWA, were also on the same group of medications. It is noteworthy that, apart from SSRI/TCA use in four patients detailed above, no other medications used by patients in different groups are known to affect muscle tone in REM sleep, except for potential for some anti-psychotic medications used for patients with autism.

\section{Discussion}

This is the largest study reporting REM sleep characteristics of young subjects with RBD, as well as those with other 
Table 3: Clinical presentation, additional clinical details, and video-PSG findings of young patients undergoing video-PSG evaluation for suspected RBD and with a final diagnosis of RBD $(\mathbf{N}=12)$

\begin{tabular}{|c|c|c|c|c|c|c|}
\hline S. No. & Age/Sex & Clinical presentation & $\begin{array}{l}\text { Associated } \\
\text { condition }\end{array}$ & History & Medication & PSG/Video findings \\
\hline 1 & $18 / \mathrm{M}$ & $\begin{array}{l}\text { Episodes of abnormal behavior in sleep daily } \\
\text { for last } 12 \text { years. } \\
\text { Consisting of mumbling, crying, rolling, and } \\
\text { blinking of eyes. } \\
\text { Sometimes associated with shivering and } \\
\text { delayed response to calling. } \\
\text { Episodes occurring } 1-2 \text { hours after sleep onset, } \\
\text { no day time events. Family history positive } \\
\text { in } 32 \text {-year-old maternal uncle. MRI brain } \\
\text { normal. }\end{array}$ & $\begin{array}{l}\text { Narcotic drug } \\
\text { addiction }\end{array}$ & $\begin{array}{l}\text { Nocturnal episodes } \\
\text { with family history }\end{array}$ & $\begin{array}{l}\text { Opium } \\
\text { Cannabis } \\
\text { Tobacco } \\
\text { "Apra" } \\
\text { "Spasmindon" } \\
\text { Cyclodon }\end{array}$ & $\begin{array}{l}\text { Four events recorded in REM } \\
\text { sleep: gesturing movements with } \\
\text { both upper limbs, mumbling } \\
\text { (none during NREM sleep) } \\
\text { ETMA + SMA } \\
\text { AHI }=0.69, \text { REM } \% 17, \\
\text { Arousal index }=16\end{array}$ \\
\hline 2 & $10 / \mathrm{M}$ & $\begin{array}{l}\text { Recurrent episodes of hyperventilation lasting } \\
\text { for several minutes, with thrashing of limbs } \\
\text { since July 2010, always about } 2 \text { hours after } \\
\text { sleep onset. } \\
\text { CT scan (Head) showed left parietal } \\
\text { inflammatory granuloma. }\end{array}$ & $\mathrm{H} / \mathrm{o}$ three seizures & GERD & Sodium valproate & $\begin{array}{l}\text { One event during REM sleep: } \\
\text { restless side-to-side movements } \\
\text { of body } \\
\text { ETMA + SMA } \\
\text { AHI }=4, \text { REM } \%=14, \\
\text { Arousal Index }=16\end{array}$ \\
\hline 3 & $22 / \mathrm{M}$ & $\begin{array}{l}\text { Abnormal Behavior in sleep, elaborate sexual } \\
\text { behavior present during episodes. } \\
\text { History of sexual harassment at age of } 6 \text { years } \\
\text { present. }\end{array}$ & $\begin{array}{l}\text { Sexsomnia- or } \\
\text { Sleep-related } \\
\text { dissociative } \\
\text { disorder with } \\
\text { sexual behaviors }\end{array}$ & $\begin{array}{l}\text { Nocturnal episodes of } \\
\text { dream-enacting } \\
\text { behavior in } 2 \text { nd part } \\
\text { of night, with } \\
\text { vocalization }\end{array}$ & None & $\begin{array}{l}\text { No events recorded } \\
\text { ETMA }\end{array}$ \\
\hline 4 & $22 / \mathrm{M}$ & $\begin{array}{l}\text { Episodes of violent behavior during sleep with } \\
\text { gesturing with both upper limbs and face of } 3 \\
\text { years duration. } \\
\text { Delayed speech milestones, mild intellectual } \\
\text { subnormality, aggressive personality. } \\
\text { History of Nocturnal enuresis }\end{array}$ & $\begin{array}{l}\text { Delayed speech, } \\
\text { nocturnal } \\
\text { enuresis }\end{array}$ & $\begin{array}{l}\text { Nocturnal episodes of } \\
\text { dream-enacting } \\
\text { behavior in } 2 \text { nd part } \\
\text { of night, with } \\
\text { vocalization }\end{array}$ & $\begin{array}{l}\text { Risperidone (prescribed for } \\
\text { behavioral problems) }\end{array}$ & $\begin{array}{l}\text { No events recorded } \\
\text { ETMA + SMA }\end{array}$ \\
\hline 5 & $20 / \mathrm{M}$ & $\begin{array}{l}\text { History of episodic abnormal gesturing and } \\
\text { vocalization during sleep, starting an hour } \\
\text { after sleep onset, several episodes per night } \\
\text { sometimes. }\end{array}$ & $\begin{array}{l}\text { Night terror and } \\
\text { confusional } \\
\text { arousal }\end{array}$ & $\begin{array}{l}\text { Dream-enacting } \\
\text { behavior while } \\
\text { sleeping }\end{array}$ & $\begin{array}{l}\text { Olanzepine (prescribed by } \\
\text { psychiatrist for the } \\
\text { nocturnal behaviors) }\end{array}$ & $\begin{array}{l}\text { No events recorded } \\
\text { ETMA }\end{array}$ \\
\hline 6 & $13 / \mathrm{M}$ & $\begin{array}{l}\text { History of talking about daytime events during } \\
\text { sleep, occasionally trying to get up and sit in } \\
\text { bed, for last } 2 \text { years. } \\
\text { H/O two episode of seizures several years } \\
\text { back, no recurrence after treatment with } \\
\text { Carbamazepine for } 2 \text { years. }\end{array}$ & Seizures & $\begin{array}{l}\text { H/o sleep-onset } \\
\text { hallucinations and } \\
\text { sleep talking }\end{array}$ & None & $\begin{array}{l}\text { No events recorded } \\
\text { ETMA + SMA } \\
\text { AHI }=1.41, \text { REM } \% 19, \\
\text { Arousal index }=18.2\end{array}$ \\
\hline 7 & $23 / \mathrm{M}$ & $\begin{array}{l}\text { Episodes of limb thrashing and talking in } \\
\text { sleep. Diagnosed to have obsessive- } \\
\text { compulsive disorder and also has initiation } \\
\text { insomnia. }\end{array}$ & $\begin{array}{l}\text { OCD } \\
\text { TTH }\end{array}$ & $\begin{array}{l}\text { Dream-enacting } \\
\text { behavior in sleep. } \\
\text { Problem in sleep } \\
\text { initiation }\end{array}$ & $\begin{array}{l}\text { Fluoxetine } \\
\text { (possible SSRI } \\
\text { medication-induced } \\
\text { RBD) }\end{array}$ & $\begin{array}{l}\text { One event recorded: dream } \\
\text { enactment with vivid gesturing } \\
\text { and talking during first REM } \\
\text { episode } \\
\text { ETMA } \\
\text { AHI }=0.8, \text { REM } \% 15 \text {, } \\
\text { Arousal index }=27\end{array}$ \\
\hline 8 & $25 / \mathrm{M}$ & $\begin{array}{l}\text { Episodes of getting up in bed and abnormal } \\
\text { behavior, once in 2-3 months for last } 1 \text { year. } \\
\text { Mother complains about keeping company } \\
\text { with anti-social persons }\end{array}$ & $\begin{array}{l}\text { Somnambulism, } \\
\text { psychological } \\
\text { stressors }\end{array}$ & $\begin{array}{l}\text { Dream-enacting } \\
\text { behavior in sleep. }\end{array}$ & $\begin{array}{l}\text { Escitalopram (possible } \\
\text { SSRI medication-induced } \\
\text { RBD) }\end{array}$ & $\begin{array}{l}\text { No events recorded } \\
\text { ETMA + SMA } \\
\mathrm{AHI}=5, \mathrm{REM} \%=31, \\
\text { Arousal index }=14.3\end{array}$ \\
\hline 9 & $18 / \mathrm{M}$ & $\begin{array}{l}\text { Excessive daytime somnolence with single } \\
\text { episode of sleep-onset hallucination - } \\
5 \text { years }\end{array}$ & $\begin{array}{l}\text { Idiopathic } \\
\text { hypersomnia }\end{array}$ & EDS & Modafinil & $\begin{array}{l}\text { Two events recorded: unclear } \\
\text { semi-purposive movements only } \\
\text { during REM episodes } \\
\text { AHI }=3.26, \text { REM } \%=18, \\
\text { Arousal index }=8\end{array}$ \\
\hline 10 & $8 / \mathrm{M}$ & $\begin{array}{l}\text { Excessive daytime somnolence and history } \\
\text { suggestive of Cataplexy for last } 3 \text { years. } \\
\text { Delayed speech milestones, but normal } \\
\text { intelligence. Polydactyly in both lower } \\
\text { limbs. }\end{array}$ & $\begin{array}{l}\text { Delayed speech, } \\
\text { Polydactyly in } \\
\text { both lower limbs } \\
\text { Narcolepsy }\end{array}$ & $\begin{array}{l}\text { EDS and Cataplexy } \\
\text { Dream-enacting } \\
\text { behavior }\end{array}$ & $\begin{array}{l}\text { Modafinil and TCA (the } \\
\text { TCA can trigger or } \\
\text { exacerbate RBD) }\end{array}$ & $\begin{array}{l}\text { Two events: body movements and } \\
\text { facial grimacing as if in } \\
\text { conversation - in REM sleep? } \\
\text { ETMA } \\
\text { AHI }=2.69, \text { REM } \%=14, \\
\text { Arousal index }=14\end{array}$ \\
\hline
\end{tabular}


Table 3: (Continued)

\begin{tabular}{l|c|l|l|l|l|l}
\hline S. No. & Age/Sex & Clinical presentation & $\begin{array}{l}\text { Associated } \\
\text { condition }\end{array}$ & History & Medication & PSG/Video findings \\
\hline 11 & $9 / \mathrm{M}$ & $\begin{array}{l}\text { Excessive daytime somnolence with sleep } \\
\text { attacks for last 4 years, along with several } \\
\text { episodes suggestive of cataplexy }\end{array}$ & Narcolepsy & EDS and cataplexy & Modafinil, TCA & $\begin{array}{c}\text { One event: low amplitude } \\
\text { repetitive kicking movements } \\
\text { ETMA + SMA } \\
\text { AHI }=0.83, \text { REM } \%=18, \\
\text { Arousal index }=11\end{array}$ \\
\hline 12 & $3 / \mathrm{M}$ & $\begin{array}{l}\text { History of rhythmic body movements at sleep } \\
\text { onset, and several times during night-time } \\
\text { sleep - for last one and a half year. History of } \\
\text { restless legs syndrome, responsive to oral } \\
\text { iron therapy - 6 months. }\end{array}$ & RMD, RLS & $\begin{array}{l}\text { Cries excessively on } \\
\text { sleep initiation }\end{array}$ & Oral Iron & $\begin{array}{c}\text { Rhythmic movements of both } \\
\text { lower limbs only during REM } \\
\text { sleep } \\
\text { ETMA + SMA } \\
\text { AHI }=0.83, \text { REM\% }=18, \\
\text { Arousal index }=11\end{array}$ \\
\hline
\end{tabular}

$\mathrm{AHI}=$ apnea hypopnea index, EDS $=$ excessive daytime sleepiness, GERD = gastroesophageal reflux disorder, NDD $=$ neurodevelopmental disorder, $\mathrm{OCD}=$ obsessive compulsive disorder, RLS $=$ restless legs syndrome, RMD $=$ rhythmic movement disorder, TTH $=$ tension type headache

Table 4: Review of published Case reports and series of RBD and RWA in young

\begin{tabular}{|c|c|c|c|c|}
\hline Reference & $\begin{array}{l}\text { Type of study details } \\
\text { reported }\end{array}$ & Associated condition & Clinical/PSG data & Remarks \\
\hline Barros Ferreira et al. ${ }^{3}$ & $\begin{array}{l}\text { Case report } \\
8 \mathrm{~F}\end{array}$ & Infiltrating Pontine tumor & Movements during REM sleep & \\
\hline Schenck et al. ${ }^{4}$ & $\begin{array}{l}\text { Case report } \\
10 \mathrm{~F}\end{array}$ & $\begin{array}{l}\text { After removal of middle cerebellar } \\
\text { Astrocytoma }\end{array}$ & Movements during REM sleep & $\begin{array}{l}\text { 8-year-old brother had same } \\
\text { findings }\end{array}$ \\
\hline Sheldon et al. ${ }^{14}$ & $\begin{array}{l}\text { Case Series } \\
\text { five patients }\end{array}$ & $\begin{array}{l}\text { One patient had Narcolepsy, others } \\
\text { characterized as Idiopathic }\end{array}$ & $\begin{array}{l}\text { Complex motor behavior associated with } \\
\text { dreams }\end{array}$ & $\begin{array}{l}\text { Responded well to } \\
\text { Clonazepam }\end{array}$ \\
\hline Thirumalai et al. ${ }^{8}$ & $\begin{array}{l}\text { Prospective PSG study } \\
5 / 11 \text { found to have RBD }\end{array}$ & Autism spectrum disorder & Both clinical and PSG findings of RBD & $\begin{array}{l}\text { 4/5 responded well to } \\
\text { Clonazepam }\end{array}$ \\
\hline Blaw et al. ${ }^{15}$ Herman $^{16}$ & $\begin{array}{l}\text { Case reports } \\
2 \text { year/Male } \\
18 \text { month/Male }\end{array}$ & Hereditary quivering with tongue biting & $\begin{array}{l}\text { Complex motor behavior and loss of } \\
\text { REM atonia }\end{array}$ & $\begin{array}{l}\text { Both improved with } \\
\text { Clonazepam }\end{array}$ \\
\hline Trajanovie et al. ${ }^{17}$ & $\begin{array}{l}\text { Case report } \\
4 \text { year old /Male }\end{array}$ & Tourette's Syndrome & $\begin{array}{l}\text { Move in sleep, flail his hand and vocalize } \\
\text { RWA + nt }\end{array}$ & No pharmacological treatment \\
\hline Nevsimalova et al. ${ }^{18}$ & $\begin{array}{l}\text { Case report } \\
7 \text { and } 9 \text { year/Female }\end{array}$ & Narcolepsy & $\begin{array}{l}\text { 1st: harmful behavior and sleep-talking } \\
\text { appeared. Attacked sister, kicking, and } \\
\text { striking wall repeatedly } \\
\text { 2nd sleep talking and complex } \\
\text { movements }\end{array}$ & Treated with Clonazepam \\
\hline Turner et al. ${ }^{19}$ & Case report & Narcolepsy & & \\
\hline Lloyd et al. ${ }^{12}$ & $\begin{array}{l}\text { Reported } 15 \text { cases of RBD in } \\
\text { children and adolescents }\end{array}$ & $\begin{array}{l}\text { Anxiety, ADHD, NDD, Smith Magenis } \\
\text { Syndrome, Pervasive developmental } \\
\text { disorder, Narcolepsy, Idiopathic } \\
\text { hypersomnia, and Moebius syndrome }\end{array}$ & RBD and RWA & $\begin{array}{l}\text { One patient developed } \\
\text { depression and ADHD on a } \\
\text { 6-year follow-up. }\end{array}$ \\
\hline Rye et al. ${ }^{7}$ & Case reports & $\begin{array}{l}\text { Juvenile PD, NDD, Narcolepsy, } \\
\text { Medication }\end{array}$ & RWA & \\
\hline
\end{tabular}

neurological disorders. While quantitative analysis of the REM periods of the young patients suffering from RBD is presented, the main observations made are of a large proportion of PSG studies of patients diagnosed with autism spectrum disorders and those with ADHD also show loss of normal REM-associated atonia during nearly $10 \%$ of the REM epochs recorded. This compares with no similar findings among normal age-matched subjects and a small percentage of patients with epilepsy.

RBD among children, adolescents, and young adults has been reported only in small case series and is evidently an uncommon clinical problem. Lloyd et al. reported a series of 15 patients younger than 18 years of age, with RBD, 2 of which had only RWA. The associated co-morbidities and response to treatment were similar to our observations, in the group of RBD patients reported. ${ }^{12}$ Another series of 22 patients younger than 40 years age also reported similar clinical and PSG findings. ${ }^{13}$ Apart from these a number of case reports have been published and co-morbidities ranging from brainstem tumors to juvenile Parkinson's disease have been observed with young RBD (Table 4). The interesting and novel part of our study is the 
observation of RWA and motor behaviors recorded during REM sleep of children with autism, ADHD, and some children with epilepsy, which may not necessarily give the appearance of dream enactment as often and as clearly as in adults. ${ }^{6,14-18,20}$ History of episodic abnormal behaviors during sleep was not reported for any subjects apart from the group which presented with suspected parasomnia. This can be attributable to the often non-specific and non-stereotyped characteristics of behaviors and abnormal movements observed on video among patients included. Many abnormal behaviors are commonly observed among patients with autism spectrum disorders, and it is possible that caregivers would be unable to differentiate between behaviors observed during wakefulness versus those in sleep. Hancock et al. studied RWA quantification in children with RBD and a control group without RBD and found significantly greater amounts of RWA among the former. ${ }^{19}$

We categorized RWA features in greater detail than required per the AASM guidelines for RWA among adults. Apart from the requirement by AASM guidelines for greater than $50 \%$ of 10 three-second mini-epochs for labeling any particular epoch to show ETMA or SMA, various cut-off percentages for individual muscles and muscle combinations showing RWA have been identified, for the diagnosis of RBD, in previous studies. These authors found that for clinical purposes, a cut-off of $18.2 \%$ of "any," that is, tonic or phasic or both EMG activity in the mentalis muscle was sufficient for diagnosis of RBD. ${ }^{21}$ We have reported our analysis by both, this less stringent cut-off as well as that of $50 \%$, for the epochs showing increased muscle tone during REM sleep. Some other authors reporting EMG quantification among patients with RBD have also aimed at identifying cut-off values to label abnormal muscle tone during REM sleep indicative of a diagnosis of RBD. ${ }^{22}$ Postuma et al. suggest that the amount of RWA appears to predict the development of PD, showing that idiopathic RBD patients who developed PD had baseline abnormal tonic chin muscle activity of $73 \%$ compared to $41 \%$ of those who remained disease free. They also reported high RWA rates $(54 \%)$ among those suffering from Lewy body dementia. ${ }^{23}$ Nevertheless, it is important to note that such quantification and cut-off rates for RWA, as well as values correlative with clinical RBD are currently unavailable, for younger patients presenting with RBD or those whose PSG shows only RWA. Our study is important in gathering information required to establish clinical significance of the unusual PSG findings among various young populations studied by us.

The finding of prominent RWA among young patients with various disorders studied by us, notably autism as well as ADHD, has not been reported before. The clinical and, especially, the prognostic implications should be of considerable interest and should encourage future research in this area. An observation of prognostic concern from recent studies is the higher prevalence of Parkinson's disease than normal age-matched population, among adults with autism. ${ }^{24,25}$ In addition, mutations in the Parkinson's disease-associated, G-Protein-coupled receptor 37 (GPR37) gene, which is associated with the dopamine transporter, have been identified in some patients with the autism spectrum disorder and proposed to be related to the deleterious effects of the autism spectrum disorders. ${ }^{26}$ Such genetic associations among Parkinsonism with ADHD and autism have also been a matter of intensive exploration and may be of relevance to patients with autism and ADHD with RWA/RBD. ${ }^{27-29}$
While this is the first large study on RWA and RBD in children, adolescents, and young adults, its limitations are the small numbers in each group and non-availability of adequate follow-up data for most of these.

\section{Conclusion}

We observed that a large percentage of young patients with autism and ADHD and some with epilepsy demonstrate loss of REM-associated atonia and some RBD-like behaviors on polysomnography similar to young patients presenting with RBD. The clinical significance of this finding thus forms an interesting subject of future research.

\section{ACKNOWLedGements}

Authors are grateful for the help in data entry and secretarial assistance provided by Jyoti Katoch, Tukaram Iyer and for the data acquisition carried out by sleep technologists Bharat Singh, Nikhil Kumar, and Rahul Rawat. We also acknowledge and deeply appreciate the help received from Dr. Carlos H. Schenck, with his valuable comments and suggestions toward improvement of this manuscript.

\section{Statement of Authorship}

GS - conceptualization, manuscript writing. AG - polysomnography analysis and interpretation, data analysis, manuscript writing. KC - data collection for epilepsy patients. AR - clinical data collection for patients with autism spectrum disorder and normal controls, analysis of data for these groups. AAJ - clinical data collection and analysis for patients with ADHD. MM - study planning and supervision of ADHD data management. SG supervision of autism data collection. MK - supervision of autism data analysis and interpretation. MA - data collation, manuscript editing. SP - data collation.

\section{Disclosure}

None of the authors have any financial support or conflicts of interest to disclose.

\section{REFERENCES}

1. Avidan AY, Kaplish N. The parasomnias: epidemiology, clinical features, and diagnostic approach. Clin Chest Med 2010;31: 353-70.

2. Schenck CH, Boeve BF, Mahowald MW. Delayed emergence of a parkinsonian disorder or dementia in $81 \%$ of older men initially diagnosed with idiopathic rapid eye movement sleep behavior disorder: a 16-year update on a previously reported series. Sleep Med 2013;14:744-8.

3. De Barros-Ferreira M, Chodkiewicz JP, Lairy GC, Salzarulo P. Disorganized relations of tonic and phasic events of REM sleep in a case of brain-stem tumour. Electroencephalogr Clin Neurophysiol 1975;38:203-7.

4. Schenck CH, Bundlie SR, Smith SA, Ettinger MG, Mahowald MW. REM behavior disorder in a 10 year old girl and aperiodic REM and NREM sleep movements in an 8 year old brother. Sleep Res 1986;15:162.

5. Schenck $\mathrm{CH}$, Mahowald MW. Motor dyscontrol in narcolepsy: rapid-eye-movement (REM) sleep without atonia and REM sleep behavior disorder. Ann Neurol 1992;32:3-10.

6. Nevsimalova S, Prihodova I, Kemlink D, Lin L, Mignot E. REM behavior disorder (RBD) can be one of the first symptoms of childhood narcolepsy. Sleep Med. 2007;8:784-6. 
7. Rye DB, Johnston LH, Watts RL, Bliwise DL. Juvenile Parkinson's disease with REM sleep behavior disorder, sleepiness, and daytime REM onset. Neurology 1999;53:1868-70.

8. Thirumalai SS, Shubin RA, Robinson R. Rapid eye movement sleep behavior disorder in children with autism. J Child Neurol 2002;17:173-8.

9. McCarter SJ, Louis EK, Boeve BF. REM sleep behavior disorder and REM sleep without atonia as an early manifestation of degenerative neurological disease. Curr Neurol Neurosci Rep 2012;12:182-92.

10. Berry RB, Budhiraja R, Gottlieb DJ, et al. Rules for scoring respiratory events in sleep: update of the 2007 AASM Manual for the Scoring of Sleep and Associated Events. Deliberations of the Sleep Apnea Definitions Task Force of the American Academy of Sleep Medicine. J Clin Sleep Med 2012;8: 597-619.

11. Thorpy M. International classification of sleep disorders. In: Sleep disorders medicine, New York: Springer; 2017. pp. 475-484.

12. Lloyd R, Tippmann-Peikert M, Slocumb N, Kotagal S. Characteristics of REM sleep behavior disorder in childhood. J Clin Sleep Med 2012;8:127.

13. Song P, Joo EY. Polysomnography findings of rapid eye movement sleep behavior disorder in Korean young age population. J Korean Sleep Res Soc 2014;11:57-60.

14. Sheldon SH, Jacobsen J. REM-sleep motor disorder in children. J Child Neurol 1998;13:257-60.

15. Blaw ME, Leroy RF, Steinberg JB, Herman J. Hereditary quivering chin and REM behavioral-disorder. Ann Neurol 1989; 26:471.

16. Herman JH, Blaw ME, Steinberg JB. REM behavior disorder in a two year old male with evidence of brainstem pathology. Sleep Res 1989;18:242.

17. Trajanovic NN, Voloh I, Shapiro CM, Sandor P. REM sleep behaviour disorder in a child with Tourette's syndrome. Can J Neurol Sci 2004;31:572-5.
18. Turner R, Allen WT. REM sleep behavior disorder associated with narcolepsy in an adolescent: a case report. Sleep Res 1990; 19:302.

19. Hancock KL, St Louis EK, McCarter SJ, et al. Quantitative analyses of REM sleep without atonia in children and adolescents with REM sleep behavior disorder. Minn Med 2014;97:43.

20. Ross RJ, Ball WA, Dinges DF, et al. Motor dysfunction during sleep in posttraumatic stress disorder. Sleep 1994;17:723-32.

21. Frauscher B, Iranzo A, Gaig C, et al. Normative EMG values during REM sleep for the diagnosis of REM sleep behavior disorder. Sleep 2012;35:835-47.

22. Consens FB, Chervin RD, Koeppe RA, et al. Validation of a polysomnographic score for REM sleep behavior disorder. Sleep 2005;28:993-7.

23. Postuma RB, Gagnon JF, Rompré S, Montplaisir JY. Severity of REM atonia loss in idiopathic REM sleep behavior disorder predicts Parkinson disease. Neurology 2010;74:239-44.

24. Starkstein S, Gellar S, Parlier M, Payne L, Piven J. High rates of parkinsonism in adults with autism. J Neurodev Disord 2015; 7:29.

25. Croen LA, Zerbo O, Qian Y, et al. The health status of adults on the autism spectrum. Autism 2015;19:814-23.

26. Fujita-Jimbo E, Yu ZL, Li H, et al. Mutation in Parkinson diseaseassociated, G-protein-coupled receptor 37 (GPR37/PaelR) is related to autism spectrum disorder. PloS One 2012;7:e51155.

27. Jarick I, Volckmar AL, Pütter C, et al. Genome-wide analysis of rare copy number variations reveals PARK2 as a candidate gene for attention-deficit/hyperactivity disorder. Mol Psychiatry 2014; 19:115.

28. Hansen FH, Skjørringe T, Yasmeen S, et al. Missense dopamine transporter mutations associate with adult parkinsonism and ADHD. J Clin Invest 2014;124:3107-20.

29. Yin CL, Chen HI, Li LH, et al. Genome-wide analysis of copy number variations identifies PARK2 as a candidate gene for autism spectrum disorder. Mol Autism 2016;7:23. 